\title{
Strategic management of competitiveness of energy enterprises
}

\author{
Galina Timofeeva ${ }^{1, *}$, Raisya Akmaeva ${ }^{2}$ and Aygul Aytpaeva ${ }^{2}$ \\ ${ }^{1}$ The Russian Presidential Academy of National Economy and Public Administration, 84, Vernadsky \\ Avenue, Moscow, 119606, Russia \\ ${ }^{2}$ Astrakhan State University, 20a Tatishchev Street, Astrakhan, 414056, Russia
}

\begin{abstract}
Nowadays, Russia is implementing its strategy of import substitution in main sectors of the national economy, including agriculture. Its goal in agriculture is to achieve certain indices of food self-sufficiency in basic types of food. An urgent question arises of how to achieve food security at federal and regional levels. The study methodology is based on achievements of classical and neoclassical economics in the field of competition analysis, theory of agricultural economy, strategic management school in the sphere of studying competitive advantages and assessment of competitiveness of different-level economic systems. Strategic management implies performing SWOT analysis, identifying the mission and goals of sustainable development of the regional agroindustrial complex, involving implementation of energy-efficiency policy, optimization of the crop areas structure and systemic development of fodder and livestock production.
\end{abstract}

\section{Introduction}

At the modern stage of economic theory development, studying the issues of competition and its connection with food security is becoming very urgent and integrated. Both concepts are interrelated, as an adequate competitive mechanism is an efficient tool for achieving and raising regional competitiveness.

A significant contribution to the development of the theory and practice of raising competitiveness of different-level economic systems has been made by such foreign researchers as H.I. Ansoff [1], A.D. Jr. Chandler [2], R. Charan \& G. Colvin [3], C.K. Prahalad \& G. Hamel [4], M.E. Porter [5], R. Meyer \& B. De Wit [6] and others. For example, within the framework of the competition theory development, H.I. Ansoff created a classification of management decisions, partially based on A.D. Chandler's book "Strategy and Structure" of 1962. This classification of decisions was called "strategystructure-system" or "3S model". H. I. Ansoff stated that a core competence must be marked out in the set of company's functions.

The idea was later developed by G. Hamel and C.K. Prahalad, who divided core competences into two groups. The first group is "skills and abilities that allow the company to provide consumers with fundamental benefits". The second group is a set of skills and

\footnotetext{
*Corresponding author: gv.timofeeva@igsu.ru
} 
technologies, gained knowledge and experience that become a basis for the company's successful competition. Therefore, core competences ensure organization's competitiveness at the market and are a subject of strategic management studies. The main idea of strategic management founders is that under conditions of unstable external environment, each company has to develop an economic and organizational mechanism for achieving and maintaining competitive advantages in the long run. A lot of companies around the world have introduced strategic management, which has improved their competitive positions.

At the same time, this issue is still poorly developed in the agricultural sector of economy. A lot of foreign researchers have studied the issue of food security without any focus on the necessity to introduce strategic management of the agricultural sector in order to raise its competitiveness.

Papers of such foreign scientists as P. Ehrlich [7], O. Flaten \& S. Hisano [8], D. John Shaw [9], Joseph H. Hülse [10], J. Rogers [11] and others are of methodological and practical importance for the development of conditions for food provision. At the same time, a constantly changing demand, raising food quality standards and population's growing needs, emerging markets of new food products put forward new urgent problems and solutions on the basis of new approaches to food security provision.

Basic issues of competition development in different areas have been studied by such Russian scientists as R.I. Akmaeva [12], A.I. Altukhov [13], G.V. Bespakhotny [14], V.A. Dobrynin [15] and V.V. Miloserdov [16]. Food security issues are covered in papers of the following Russian researchers: E.A. Antamoshkina [17], N.P. Ketova \& V.N. Ovchinnikova [18], E.N. Krylatykh [19], G.V. Timofeeva [20, 21] and others. A significant contribution to the development of competiveness of the agro-industrial complex was made by A.V. Petrikov [22], I.G. Ushachev [23] and A.A. Shutkov [24]. These studies have resulted in a rich research material, consisting of theoretical and methodological approaches to the issues of forming competitive advantages of certain regions, socioeconomic systems and economic entities.

However, the problem of competitiveness and food security on the basis of energyefficiency technologies, which has not been solved in Russia yet, has set new tasks on introducing a system of strategic management at regional level.

\section{Materials and Methods}

One of the strategic management functions is strategic planning which is a process of choosing organizational goals and ways to achieve them. It is the basis for making all management decisions [12]. Strategic planning consists of several stages: 1) analysis of the environment; 2) determination of the mission and goals; 3) choice of the strategy; 4) implementation of the strategy; 5) implementation assessment and control.

Let us consider the state of food security on the example of Astrakhan region.

From 2012 to 2016, Astrakhan region demonstrated an ongoing growth of agricultural production volume (in monetary terms - more than 1.6 times increase from 24.7 to 39.7 million RUB), including 1.7 times increase in crop farming and 1.5 times increase in livestock production (see Table 1). The geographical location of Astrakhan region, as well as its natural and climatic features (sharply continental arid climate, prevailing flat and steppe types of relief) have had a significant impact on the development of the regional agriculture. Potato and vegetable production takes the lead in the region. In 2016, the vegetable production volumes increased 3.2 times in comparison with 2004 , and the potato production increased 2.7 times as well (Table 2 ). 
Table 1. Agricultural production (expressed in prices, actual at the period under consideration, million RUB) (Source: data from the Federal State Statistics Service).

\begin{tabular}{|l|c|c|c|c|c|c|}
\hline & & & & & & $\begin{array}{c}\text { 2016 in } \\
\text { comparison } \\
\text { with 2012, } \\
\%\end{array}$ \\
\hline $\begin{array}{l}\text { Agriculture } \\
\text { - total amount, } \\
\text { including: }\end{array}$ & $24,717.70$ & $28,235.50$ & $31,023.60$ & $38,871.30$ & $39,784.60$ & 60.96 \\
\hline crop farming & $13,630.80$ & $15,931.90$ & $17,607.50$ & $23,572.00$ & $23,287.00$ & 70.84 \\
\hline $\begin{array}{l}\text { Livestock } \\
\text { production }\end{array}$ & $11,086.90$ & $12,303.60$ & $13,416.10$ & $15,299.30$ & $16,497.70$ & 48.80 \\
\hline
\end{tabular}

Table 2. Comparative dynamics by production volumes, thousand tons (Source: data from the Federal State Statistics Service).

\begin{tabular}{|l|c|c|}
\hline Production type & 2016 & 2004 \\
\hline Vegetable production & 905.3 & 283.5 \\
\hline Potato production & 315.3 & 116.4 \\
\hline
\end{tabular}

Astrakhan region constantly develops livestock production, another sector of agriculture.

At the same time, rural districts of Astrakhan region differ by volume of their contribution to the regional food production. It largely depends on the area of irrigated arable lands because Astrakhan region belongs to the arid zone and it seems impossible to develop crop farming under rainfed conditions.

Table 3. Assessment of irrigated lands and crop zoning by ecological types, depending on soil and climate conditions of Astrakhan region (Source: compiled by the authors according to the data, provided by the Ministry of Agriculture and Fisheries of Astrakhan region).

\begin{tabular}{|l|c|c|c|c|}
\hline \multicolumn{1}{|c|}{ District } & $\begin{array}{c}\text { Area of } \\
\text { irrigated } \\
\text { lands used, } \\
\text { ha }\end{array}$ & $\begin{array}{c}\text { Quality } \\
\text { index, score }\end{array}$ & $\begin{array}{c}\text { Total precipitation } \\
\text { over the period } \\
\text { with a temperature } \\
\text { higher than } 10 \mathrm{C}^{\circ}, \\
\mathrm{mm}\end{array}$ & $\begin{array}{c}\text { Ecological types of } \\
\text { cultivated crops }\end{array}$ \\
\hline Chernoyarsky & $11,254.0$ & 35 & 150 & $\begin{array}{c}\text { Crops, vegetables, melons, } \\
\text { onion, potatoes, fruit }\end{array}$ \\
\hline Akhtubinsky & $7,726.0$ & 31 & $100-150$ & $\begin{array}{c}\text { Crops, vegetables, melons, } \\
\text { rice, fruit }\end{array}$ \\
\hline Enotaevsky & $4,530.0$ & 28 & $100-150$ & $\begin{array}{c}\text { Potatoes, fodder grasses, } \\
\text { crops }\end{array}$ \\
\hline Kharabalinsky & $10,660.0$ & 44 & $100-150$ & $\begin{array}{c}\text { Vegetables, potatoes, fruit, } \\
\text { medick }\end{array}$ \\
\hline Narimanovsky & $2,788.0$ & 35 & $100-150$ & $\begin{array}{c}\text { Fodder grasses, vegetables, } \\
\text { popatoes }\end{array}$ \\
\hline Krasnoyarsky & $4,028.0$ & $\begin{array}{c}\text { (floodplain } \\
\text { soils) }\end{array}$ & $100-125$ & $\begin{array}{c}\text { Fodder grasses, rice } \\
\text { Ikryaninsky }\end{array}$ \\
\hline Limansky & $8,930.0$ & 45 & $100-125$ & $\begin{array}{c}\text { Fruit, grapes, vegetables, } \\
\text { melons, fodder grasses }\end{array}$ \\
\hline
\end{tabular}




\begin{tabular}{|l|c|c|c|c|}
\hline & & & & plant, potatoes \\
\hline Delta & & & & $\begin{array}{c}\text { Fruit, grapes, vegetables, } \\
\text { melons }\end{array}$ \\
Privolzhsky, & & & & \\
Kamyzyaksky, & 9,780 & 60 & & \\
Volodarsky and & 10,098 & 59 & $100-110$ & \\
the southern part & 3,694 & 52 & & \\
of the & & & & \\
Ikryaninsky & & & & \\
district & $76,368.0$ & & & \\
\hline Total & & & \\
\hline
\end{tabular}

The quality index of the majority of the regional irrigated lands is quite low. The total land area grows extensively, which affects further development. The potato crops occupy more that $50 \%$ of the total cultivated area, which poses a threat to efficient use of land resources in Astrakhan region, as single cropping leads to accumulation of diseases and pests in soil. All the above circumstances require performing a serious analysis and taking specific measures, aimed at reduction of the area of unused arable lands, hayfields and pastures in the region.

The study was carried out with the use of such specific methods as SWOT analysis of competitiveness of the regional agro-industrial complex (AIC), a comparative analysis, methods for predicting quantitative and qualitative benchmarks of the regional AIC development.

\section{Results}

The SWOT analysis resulted in identification of several bottlenecks that affect the AIC development in Astrakhan region. These are the lack of strategic management of the regional AIC, high energy consumption of the agricultural production; poor introduction of energy-efficient combined units into the agricultural production and energy-efficient equipment at food and processing enterprises, insufficient application of energy-efficient ways of crop irrigation, insufficient rates of food export growth in the region, low rate of public procurement of agriculture, unfavourable abiotic factors of the environment, etc. One of the serious problems, leading to low-quality production, is the insufficient number of seeds and planting materials of regional and national selection (Table 4). The main cause of a decrease in the food self-sufficiency of Astrakhan region reduces to:

a) high energy consumption. Energy consumption - electricity, heating and the energy for driving mobile means of transport - forms a great deal of agricultural production costs. In the modern agricultural production, energy consumption depends on a plenty of changing factors and their different combinations (methods of soil treatment, irrigation, livestock keeping, applied means of mechanization, yield capacity of crops and livestock productivity, climate conditions, levels of mechanization and electrification of crop and livestock production processes).

The energy crisis made Western Europe, USA, Canada and Japan develop a range of economic, organizational and technological measures which allowed to ensure the agricultural production growth while reducing energy consumption. Under modern conditions, the energy consumption share in the German agricultural production costs is $7 \%$, while in Russia this share is more than $20 \%$. It raises the necessity of considering the energy consumption problem at regional and federal levels as one of the most important strategic innovations.

b) inefficient use of arable lands, non-compliance with scientifically based alternation of 
crops in time and space, ignoring principles of zoning and the widespread cultivation of vegetables and potatoes by rural goods producers. The introduction of short rotary crop rotations led to soil pollution by pathogenic microflora, a decrease in the reserves of humus, and the development of degradation processes, especially in irrigated arable lands.

The recovering of the agro-industrial complex of Astrakhan region from the protracted economic crisis, its revival and development are constantly connected with increasing the competitiveness of agricultural enterprises of AIC and saturating the consumer market with high-quality regional food products.

Table 4. SWOT analysis on the example of the regional agro-industrial complex [3]

\begin{tabular}{|c|c|}
\hline IGTHS & SES \\
\hline $\begin{array}{l}\text { 1. High potential of photosynthetically } \\
\text { active radiation in the region } \\
\text { 2. Favourable soil and climate conditions } \\
\text { 3. Diversity of agricultural lands } \\
\text { 4. Significant human resources, economic, } \\
\text { technological and engineering potential of } \\
\text { the Astrakhan AIC } \\
\text { 5. High profitability of production of } \\
\text { vegetables, melons and potatoes in the } \\
\text { region } \\
\text { 6. Great demand for food, produced in } \\
\text { Astrakhan region, among the population } \\
\text { 7. Development of import-substituting } \\
\text { production through the export of vegetables, } \\
\text { melons, potatoes and fish products }\end{array}$ & $\begin{array}{l}\text { 1. Insufficient and segmental level of agricultural } \\
\text { production management in the region. } \\
\text { 2. High energy consumption of the agricultural } \\
\text { production } \\
\text { 3. Poor introduction of energy-efficient combined units } \\
\text { into the agricultural production and energy-efficient } \\
\text { equipment at food and processing enterprises } \\
\text { 4. Insufficient application of energy-efficient drip and } \\
\text { sprinkler irrigation of crops } \\
\text { 5. Frequent droughts in Astrakhan region } \\
\text { 6. Poor development of export of most types of } \\
\text { agricultural products in the region } \\
\text { 7. Low rate of public procurement of agriculture in } \\
\text { Astrakhan region } \\
\text { 8. Inefficient development of the processing industry } \\
\text { 9. Collapse of the regional system of seed production, } \\
\text { dependence from import deliveries of seeds and planting } \\
\text { materials. } \\
\text { 10. Large areas of unused arable lands, hayfields and } \\
\text { pastures. }\end{array}$ \\
\hline OPPORTUNITIES & THREATS \\
\hline $\begin{array}{l}\text { 1. Increasing the state support of the } \\
\text { regional AIC due to the sanctions, imposed } \\
\text { on Russia by EU countries and USA } \\
\text { 2. Expanding the markets for the regional } \\
\text { products and entering new markets beyond } \\
\text { the region } \\
\text { 3. Improving the agricultural production } \\
\text { quality } \\
\text { 4. Broadening the production range } \\
\text { 5. Increasing the demand for high-quality, } \\
\text { biologically valid, eco- and genetically } \\
\text { harmless food products in the regional } \\
\text { production. }\end{array}$ & $\begin{array}{l}\text { 1. Low procurement prices for the agricultural products, } \\
\text { produced in the region } \\
\text { 2. Low quality of seeds and planting materials, wide } \\
\text { dissemination of genetically modified seeds of foreign } \\
\text { selection } \\
\text { 3. Poor organization of marketing services at many AIC } \\
\text { enterprises } \\
\text { 4. Low purchasing power of the population in relation to } \\
\text { high-nutrient products like meat, milk, etc. }\end{array}$ \\
\hline
\end{tabular}

In connection with the above, we can formulate the mission of the regional AIC, that is ensuring the parameters of food independence for the absolute majority of the population of the region. A "Goal Tree" which is being developed for the sustainable development of the regional AIC and which is based on a systemic approach should ensure high economic efficiency of production, processing of agricultural products and the possibility for extended reproduction (Fig.1). 


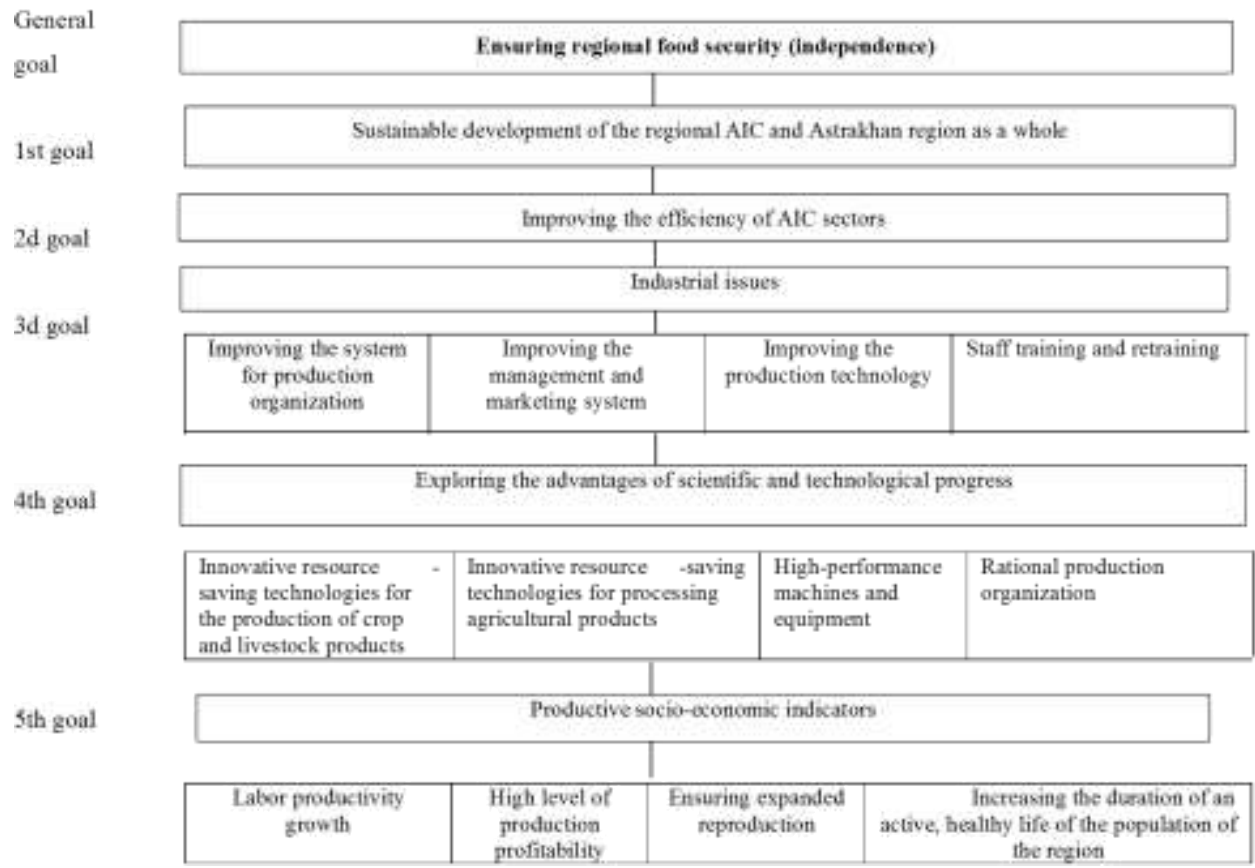

Fig. 1. "Goal Tree" for the regional AIC development .

In this regard, the analysis of the actual specialization in the production of agricultural products in rural areas of Astrakhan region is of significant importance, as well as the development of promising directions for the future on the bases of soil-climatic and economic potentials involving the maximum possible use of the natural, labor, material, technical and financial resources of agricultural enterprises operating on a specific territory.

Specialization analysis of rural areas showed that good producers in most areas of Astrakhan region prefer those directions that provide the highest possible profit, and it happens to the detriment of the development of grain production, fruit growing, fodder and, consequently, livestock production.

This circumstance negatively affects the region's food self-sufficiency and the competitiveness of the food industry.

Currently, to retain positions in the market, each enterprise and the agricultural sector of the economy need to plan strategic changes, develop and systematically adjust the marketing strategy, increase production, enter new markets, expand the range of products, meet European requirements and production standards.

In the very near future, organizational and economic measures should be developed. They should be aimed at stimulating rural producers to develop dairy and beef cattle breeding, pig breeding, chicken meat production, fruit and berry production and grain production.

The introduction of strategic management in AIC of Astrakhan region will allow to change the concept of the industry, determine the mechanisms for achieving the parameters of food security due to the increased competitiveness of agricultural products and food within the regional production. At the same time, a large role is given to the development and implementation of a strategic management system for long-term operations, the formation and development of a corporate culture at the level of agribusinesses and the agrarian sector of the economy as a whole. 
Table 5. Matrix of planning changes in the regional AIC.

\begin{tabular}{|l|c|l|}
\hline Key activities & \multicolumn{1}{|c|}{ From the past } & \multicolumn{1}{c|}{ To the future } \\
\hline AIC concept & $\begin{array}{c}\text { Production of the most } \\
\text { profitable types of } \\
\text { agricultural products: } \\
\text { vegetables, melons, } \\
\text { potatoes }\end{array}$ & $\begin{array}{l}\text { Ensuring food safety parameters for the population of } \\
\text { Astrakhan region at the expense of intra-regional } \\
\text { production of biologically valid, eco- and genetically } \\
\text { harmless food of high quality }\end{array}$ \\
\hline Markets & $\begin{array}{c}\text { Astrakhan region, } \\
\text { other regions of the } \\
\text { Russian Federation, } \\
\text { Kazakhstan }\end{array}$ & $\begin{array}{l}\text { Confident access to the non-regional markets: St. } \\
\text { Petersburg, Krasnodarskiy Krai, Stavropolskiy Krai, } \\
\text { Rostov region, Kalmykia, etc. Entry into foreign } \\
\text { markets: Belarus, Uzbekistan, etc. }\end{array}$ \\
\hline Range of goods & $\begin{array}{c}\text { Vegetables, potato, } \\
\text { market eggs, fish, etc. }\end{array}$ & $\begin{array}{l}\text { A wider range of products, the use of various } \\
\text { technologies for the production and processing of } \\
\text { meat, milk, vegetables, etc. }\end{array}$ \\
\hline $\begin{array}{l}\text { Resources and } \\
\text { operational } \\
\text { systems for } \\
\text { managing } \\
\text { short-term } \\
\text { operations }\end{array}$ & $\begin{array}{c}\text { Each AIC enterprise } \\
\text { has its own resources } \\
\text { and operations } \\
\text { management systems. }\end{array}$ & $\begin{array}{l}\text { Focusing on the exchange of best practices between } \\
\text { enterprises, using the benchmarking method, studying } \\
\text { the experience of leading enterprises. The use of } \\
\text { energy-saving combined units for tillage and } \\
\text { innovative energy-saving methods of crops irrigation }\end{array}$ \\
\hline $\begin{array}{l}\text { Strategic long- } \\
\text { term operations } \\
\text { management } \\
\text { systems }\end{array}$ & none & $\begin{array}{l}\text { Development and implementation of a strategic long- } \\
\text { term operations management system at each } \\
\text { agricultural enterprise }\end{array}$ \\
\hline $\begin{array}{l}\text { Corporate } \\
\text { culture }\end{array}$ & $\begin{array}{l}\text { Corporate culture is } \\
\text { developing }\end{array}$ & $\begin{array}{l}\text { Formalized procedures for managing corporate culture } \\
\text { at the level of the agro-industrial complex }\end{array}$ \\
\hline
\end{tabular}

Activities aimed at the effective use of the AIC resource potential

1. Implementation of energy conservation policies in agriculture.

Replacing old equipment with energy-saving combined units that perform several technological operations in one pass. Saving water consumption through the use of modern systems of drip and sprinkling irrigation.

As an example, let us consider the economic efficiency of potato production in the region using different irrigation methods (traditional sprinkling and drip irrigation). The profitability of potato production largely depends on the magnitude of total costs (production costs). At present, many AIC enterprises are implementing a "cost leadership" competitive strategy. By producing products of the same type under conditions of tough competition, they are trying to minimize costs in order to obtain the greatest profit.

Table 6. Economic efficiency of potato cultivation with different irrigation methods.

\begin{tabular}{|l|c|c|}
\hline \multicolumn{1}{|c|}{ Indicators } & Sprinkling & Drip irrigation \\
\hline Cultivated area, ha & 1 & 1 \\
\hline Yield capacity of crops, $\mathrm{t} / \mathrm{ha}$ & 25.4 & 30.5 \\
\hline Total cost, RUB'000 & 215 & 191 \\
\hline Revenues from sales, RUB'000 & 381 & 447.5 \\
\hline Unit cost, RUB'000/t & 8.5 & 6.3 \\
\hline
\end{tabular}




\begin{tabular}{|l|c|c|}
\hline Profit, RUB'000 & 166 & 256.5 \\
\hline $\begin{array}{l}\text { Economic effect, profit in RUB/costs in } \\
\text { RUB }\end{array}$ & 0.77 & 1.34 \\
\hline Rate of return, \% & 77 & 134 \\
\hline
\end{tabular}

Analysis of Table 6 showed that the use of energy-saving drip irrigation contributed to an increase in the profitability of potato production by 1.7 times as compared with traditional irrigation sprinkling.

2. Revision of the cultivated area structure with a view to its further optimization.

During the years of market reforms, the majority of farms in the region switched from multi-field to low-efficiency three-field crop rotation. At the same time, six/seven - field irrigated crop rotations are more effective in severely arid zones of Astrakhan region. Revision of crop zoning implies the definition of its rational structure. It is assumed that in 2025 cereal and leguminous crops should occupy 50 thousand hectares, fodder crops - 95, vegetable -25 , potato -15 thousand hectares around Astrakhan region as a whole.

Table 7. Planned cultivated areas of major crops in Astrakhan region (thousand hectares) (Source: calculated by the authors according to the data of the Ministry of Agriculture and Fisheries of Astrakhan region).

\begin{tabular}{|l|l|l|l|l|l|l|}
\hline \multirow{2}{*}{ Indicators } & \multicolumn{3}{c|}{$\begin{array}{c}\text { Agricultural } \\
\text { organizations }\end{array}$} & \multicolumn{2}{c|}{ Farm population } & \multicolumn{2}{c|}{$\begin{array}{l}\text { Farm and individual } \\
\text { enterprise }\end{array}$} \\
\cline { 2 - 7 } & 2017 & 2025 & 2017 & 2025 & 2017 & 2025 \\
\hline cereal crops & 4.9 & 20 & - & & 8.2 & 30 \\
\hline potato & 0.9 & 1 & 3.5 & 4 & 10.3 & 11 \\
\hline vegetables & 2.2 & 3 & 9.2 & 10 & 11.1 & 12 \\
\hline melons & 0.7 & 1 & 0.04 & 0.05 & 6.2 & 7 \\
\hline fodder crops & 6.2 & 40 & 0.07 & 2 & 8.8 & 53 \\
\hline
\end{tabular}

Predicting an increase in cultivated areas by 2025 compared with 2017 presupposes that in Astrakhan Region the areas under grain crops will increase by 3.8 times, and the growth of cultivated areas under forage crops will be $630 \%$. Changes in the structure of the cultivated areas will lead to an increase in the yield of agricultural products. Thus, for example, with an increase in yield from 2 to $3 \mathrm{t} / \mathrm{ha}$, the gross yield of grain crops in Astrakhan region in 2025 may reach 150 thousand tons (tab. 8).

Table 8. Forward looking planned yield capacity of major crops (Source: calculated by the authors according to the data of the Ministry of Agriculture and Fisheries of Astrakhan Region).

\begin{tabular}{|l|l|l|}
\hline Crop group & Planned yield for $2025, \mathrm{t} /$ ha & Gross yield, thousand tons \\
\hline Cereal crops & 3 & 150 \\
\hline Fodder Crops & $2.2 \mathrm{t}$ per feed unit & 209 \\
\hline Vegetables & 42 & 1050 \\
\hline Potato & 30 & 480 \\
\hline
\end{tabular}

Expansion of the areas under fodder crops according to the table of zoning of 
agricultural crops, restoring the potential of natural hayfields and pastures will allow to receive more than 3000 thousand tons of food units per year.

Thus, within a scientifically based approach, in the next 10 years Astrakhan region will be able to achieve $100 \%$ food independence in beef, milk and market eggs.

Table 9. The main indicators of agricultural development of Astrakhan region (Source: calculated by the authors according to the data of the Ministry of Agriculture and Fisheries of Astrakhan region).

\begin{tabular}{|l|c|}
\hline Key development indicators & 2025 \\
\hline 1. Area of restored arable land, thousand hectares & 143 \\
\hline $\begin{array}{l}\text { 2. AIC incomes from the grain harvest received on 50 } \\
\text { thousand hectares of restored arable land, billion rubles. }\end{array}$ & 1.5 \\
\hline $\begin{array}{l}\text { 3.Number of cattle in the region } \\
\text { including cows }\end{array}$ & 500 \\
\hline 4. Milk production, thousand tons & 150 \\
\hline 5. Beef production, thousand tons & 450 \\
\hline 6. Incomes from milk sale, billion rubles & 40 \\
\hline 7. Income from beef sale, billion rubles & 10 \\
\hline
\end{tabular}

With the restoration of the abandoned areas of irrigated arable land and the placement of fodder and grain crops on them, with the rational use of natural hayfields and pastures, milk production can reach 450 thousand tons, and beef production can reach 40 thousand tons by 2025 , which in money terms will be 10 and 8.5 billion rubles, respectively. Thus, an effective use of each hectare of irrigated arable land, involvement of unused irrigated massifs in circulation, saturation of crop rotations with grain and fodder crops will provide a full-fledged forage base for livestock and will generate an annual additional income of 20 billion rubles to the region's economy.

\section{Discussions}

Managing the competitiveness and food security of the region involves assessing food selfsufficiency in basic types of food, determining the deficit and surplus of production for each of them, and on this basis developing a set of organizational and management measures aimed at the on-going development of relevant industries. Under the conditions of Astrakhan region, it is necessary to develop grain production, fruit growing, fodder production and the livestock related thereto: dairy and meat cattle breeding, pig breeding and poultry farming, which will ensure sustainable and competitive development of the region.

\section{Conclusion}

Strategic management of the region's competitiveness provides for assessing the current state of agricultural production, conducting SWOT analysis, determining the mission and development goals of the agro-industrial complex, designating promising areas for its development. In modern conditions, Astrakhan region develops import-substituting production by supplying vegetables, melons and potato for export. Disproportions in the 
development of crop and livestock production lead to food insecurity for animal products, as well as for grain and fruit. The introduction of strategic management of competitiveness and food security implies the creation of conditions for ensuring the parameters of food security for the population of Astrakhan region through the regional production of biologically valid, eco- and genetically harmless food of high quality. A wider range of products can be created through the use of various technologies for the production and processing of meat, milk, vegetables, etc. Focusing on the exchange of best practices between enterprises of the agro-industrial complex, using the benchmarking method, the experience of leading enterprises will increase production volumes and competitiveness of agricultural and food products produced in the regional agriculture.

\section{References}

1. H.I. Ansoff, Strategic Management (London, 1979)

2. A.D. Chandler, The Vesible Hand (Cambridge, 1977)

3. R. Charan, G. Colvin, Why CEO's Fail, Fortune (1999)

4. C.K. Prahalad, G. Hamal, The core competence of the corporation (Cambridge, 1990)

5. M. Porter, On Competition (Moscow, 2005)

6. B. De Wit, R. Meyer, Strategy Synthesis: Resolving Strategy Paradoxes to Create Competitive Advantage (London, 2005)

7. P. Ehrlich, The Population Bomb (New York, 1968)

8. O. Flaten, S. Hisano, Agriculture and Economy 73(8), 129-136 (2007)

9. D. John Shaw, Global Food and Agricultural Institutions (London, 2009)

10. H.J. Hülse, Agriculture, and Food Security (Ottawa, 1995)

11. J. Rogers, Development Express 1, 31 (1997)

12. R.I. Akmaeva, Strategic Management (Moscow, 2010)

13. A.I. Altukhov, National Food Security: Problems and Solutions (Moscow, 2006)

14. G.V. Bespakhotny, Economics of Agricultural and Processing Enterprises 7, 24-27 (2009)

15. V.A. Dobrynin, AIC: Economics, Management 2, 53-60 (2003)

16. V.V. Miloserdov, Economics of Agricultural and Processing Enterprises 5, 14 (2009)

17. E.N. Antamoshkina, G.V. Timofeeva, Agricultural Economy in Russia 4(14), 61-65 (2014)

18. N.P. Ketova, V.N. Ovchinnikov, Journal Economic Regulation 5(2), 105-114 (2014)

19. E.N. Krylatykh, The Nikonov's readings 19, 3 (2014)

20. G.V. Timofeeva, A.A. Aytpaeva, National Interests: Priorities and Security 13(10), 1910-1926 (2017)

21. G.V. Timofeeva, R.I. Akmaeva, A.A. Aytpaeva, Bulletin of Novosibirsk State University of Economics and Management 4, 36-44 (2017)

22. A.V. Petrikov, Economics of Agricultural and Processing Enterprises 7, 1418 (2009)

23. I.G. Ushachev, Economics of Agricultural and Processing Enterprises 3, 1-9 (2009)

24. A.A. Shutkov, Food Security: Theory, Policy and Practice (Moscow, 2011) 